\title{
Shallow marine Paleodictyon from the Upper Ordovician Georgian Bay Formation of southern Ontario
}

\author{
D.C.A. Stanley and R.K. Pickerill \\ Department of Geology, University of New Brunswick, Fredericton, New Brunswick E3B 5A3, Canada
}

Date Received March 1, 1993

Date Accepted April 26, 1993

\begin{abstract}
Two specimens, and a possible third, of the ichnotaxon Paleodictyon are documented from shallow-water marine strata of the Upper Ordovician Georgian Bay Formation of southern Ontario. Its occurrence indicates that previous suggestions of a post-Early Cambrian palaeoenvironmental retreat of Paleodictyon into deeper water require some modification. Instead, the operative migratory process, at least to the Late Ordovician and possibly even longer, was one of expansion and not of retreat.
\end{abstract}

Deux spécimens, et possiblement un troisième, de la trace fossile Paléodictyon sont reconnus dans des strates marines peu profondes de la Formation de Georgian Bay de l'Ordovicien supérieur du sud de l'Ontario. Sa présence indique que les suggestions précédentes d'une retraite paléo-environnementale post-Cambrien précoce de Paléodictyon en eaux plus profondes nécessitent quelques modifications. A la place, le processus migratoire opératif, au moins jusqu'à l'Ordovicien tardif et possiblement encore plus longtemps, en était un d'expansion et non de retraite.

[Traduit par la rédaction]

\section{INTRODUCTION}

Several recent studies in ichnology have demonstrated or suggested an environmental shift in the distribution of certain marine ichnotaxa throughout their known stratigraphic range. For example, Bottjer et al. (1988) demonstrated that the ichnogenus Zoophycos Massalongo, while common in both shelf and deep-sea environments in the Palaeozoic, has only been reported from deep-sea successions in post-Palaeozoic strata. These authors also showed that Ophiomorpha Lundgren, that supposedly first appeared in Permian shallowwater environments and was common in deep-sea environments by the Cretaceous, has been distributed from nearshore to deep-sea environments since then. Similarly, Stanley and Pickerill (in press) suggested that the ichnotaxa $F$ ustiglyphus Vialov and Rhabdoglyphus Vassoievich occupied only shallow-water regimes in the Palaeozoic and deep-water regimes in the Mesozoic and Tertiary. Bottjer et al. (1988) termed the migration of marine ichnotaxa offshore into deep-water regimes but with persistence of representatives onshore as 'expansion', and movement offshore into deep-water regimes but with loss of onshore representatives as 'retreat'.

In recent contributions by Crimes and Crossley (1991) and Crimes et al. (1992) it was suggested that the ichnotaxon Paleodictyon Meneghini, the subject of this short paper, 'evolved' in shallow-water Early Cambrian regimes. These authors suggested that, with two exceptions of records of non-marine occurrences by Archer and Maples (1984) and Pickerill (1990), the ichnotaxon became restricted to deepwater marine environments in post-Early Cambrian regimes. In this contribution, not only do we record and describe the first examples of Paleodictyon from any sequence in Ontario, but also we demonstrate that its occurrence there suggests that the environmental 'retreat' intimated by Crimes and Crossley (1991) and Crimes et al. (1992) is not so straightforward as they suggested.

\section{Location, Stratigraphic and Palaeoenvironmental Setting}

Specimens discussed herein are from three locations within the Upper Ordovician (upper Maysvillian-lower Richmondian) Georgian Bay Formation of southern Ontario (Fig. 1). A single specimen was present at each of the locations and these are housed in the Royal Ontario Museum. The locations, with appropriate ROM catalogue numbers for each specimen, are:-

(1) The Humber River Valley (Baby Point), Toronto. N.T.S. co-ordinates $4834250 \mathrm{~m} \mathrm{~N} \times 620750 \mathrm{~m} \mathrm{E}$ (ROM 49424).

(2) Workman's Creek, southeast of Meaford. N.T.S. coordinates $4938000 \mathrm{~m} \mathrm{~N} \times 534800 \mathrm{~m}$ E (ROM 49624).

(3) Highway 401 at Highway 403 overpass, Mississauga. N.T.S. co-ordinates $4832500 \mathrm{~m} \mathrm{~N}$ x $620750 \mathrm{~m}$ E (ROM 49625).

The Georgian Bay Formation is an essentially siliciclastic sequence of interbedded calcareous sandstones and grey, grey-blue or green bioturbated mudstones that is about $177 \mathrm{~m}$ thick in the Toronto area and thins northward to approximately $127 \mathrm{~m}$ thick in the Georgian Bay area. The formation can be broadly categorized as upward-coarsening and upward-thickening. Mudstone with thinly-layered sandstones are predominant in its lower horizons whereas generally thicker-bedded and sandstone-dominated sequences with sub- 


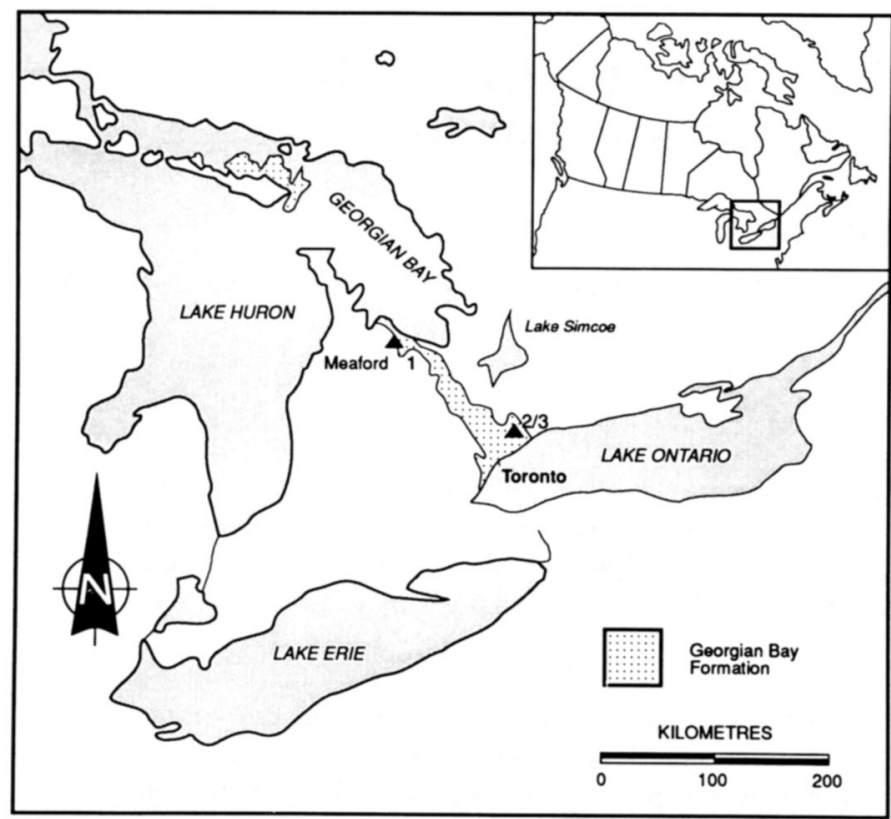

Fig. 1. Surficial distribution of the Georgian Bay Formation of southern Ontario. 1 = Workman's Creek, southeast of Meaford; 2/ 3 = Humber River Valley/Highway 401 localities (see text for details).

ordinate mudstones comprise the upper horizons. The relative proportions of mudstone-dominated and sandstonedominated sequences varies according to present-day location. The formation forms the middle part of an upward-shallowing, progradational sequence from the relatively deepwater mudstones of the underlying Blue Mountain Formation to the muddy, tidal-flat sequences of the overlying Queenston Formation (Russell and Telford, 1983; Middleton, 1987).

Kerr and Eyles (1991) have recently discussed the depositional history of the Georgian Bay Formation in some detail. These authors concluded that the sequence was deposited on a storm-influenced mid- to outer-shelf originally located in equatorial palaeolatitudes. Sedimentological observations suggested that most of the sequence was deposited between fair-weather and storm-wave base. We generally concur with this conclusion, that is also corroborated by the occurrence within the succession of trace fossils characteristic of both the shallow marine Skolithos and Cruziana ichnofacies of Seilacher $(1964,1967)$. In additon to Paleodictyon these ichnotaxa include: Arthraria antiquata, Aulichnites parkerensis, Chondrites isp., Cochlichnus anguineus, Cochlichnus isp. nov., Cruziana lobosa, Cruziana problematica, Cruziana quadrata, Cruziana isp., Curvolithus multiplex, Didymaulichnus lyelli, Diplocraterion cf. biclavatum, Diplocraterion helmerseni, Diplocraterion parallelum, Fustiglyphus annulatus, Gordia marina, Gyrochorte comosa, Helminthopsis hieroglyphica, Lingulichnus verticalis, Lockeia siliquaria, Micatuba verso, Monocraterion isp., Monomorphichnus bilinearis, Monomorphicnus lineatus, Palaeophycus annulatus, Palaeophycus heberti, Palaeophycus striatus, Palaeophycus tubularis, Phycodes flabellus, $P$ hycodes palmatus, Planolites beverleyensis, Planolites isp. nov., Rusophycus carbonarius, $R$ usophycus polonicus, $R$ usophycus cryptolithi, Rusophycus pudicus, Skolithos magnus, Skolithos verticalis, Trichophycus lanosus, Trichophycus venosus and Walcottia rugosa.

\section{Systematic Palichnology}

Ichnogenus Paleodictyon Meneghini in Murchison, 1850

Type ichnospecies: Paleodictyon strozzii Meneghini, 1850 by monotypy.

Diagnosis: Honeycomb-like network of four- to eight-sided, usually hexagonal, horizontal meshes, preserved typically in convex hyporelief, more rarely in concave epirelief. Meshes with or without vertical outlets, of variable size and shape. Outline of entire systems rounded, or more typically hexagonal (after Pickerill, 1990).

\section{Paleodictyon isp. A}

Figure 2A, B

Material: Two specimens: ROM 49424 and ROM 49624.

Description: Specimens preserved as smooth convex hyporeliefs on the soles of $2 \mathrm{~cm}$-thick, fine-grained, hummocky cross-stratified, grey calcareous sandstone layers. Both specimens consist of moderately- to well-preserved, incomplete, horizontal, irregularly polygonal meshes defined by curved to straight smooth riblets 4 to $5 \mathrm{~mm}$ in diameter, up to $3 \mathrm{~mm}$ in height, bearing elliptical cross-sections. Individual polygons, where preserved, range in size, from 1.8 to $2.9 \mathrm{~cm}$ diagonally. The two specimens cover surface areas of 24 to 56 $\mathrm{cm}^{2}$.

\section{?Paleodictyon isp. B}

Figure 2C

Material: One specimen: ROM 49625.

Description: Specimen comprises an $11 \mathrm{~cm}^{2}$, relatively complete, moderately well-preserved, though poorly-defined, horizontal mesh preserved in convex hyporelief on the sole of a $2.5 \mathrm{~cm}$ thick, fine-grained calcareous sandstone. Smooth, straight to curved riblets, 1 to $2 \mathrm{~mm}$ wide by $0.5 \mathrm{~mm}$ high, define irregular polygons ranging in size from 1 to $2 \mathrm{~mm}$ across.

Remarks: As noted by McCann and Pickerill (1988) and discussed in more detail by Crimes and Crossley (1991), ichnospecific classification of the many forms of Paleodictyon is muddled and the ichnotaxon is in need of taxonomic revision. We therefore designate our material only at the ichnogeneric rank. We do note, however, that in terms of size and overall net arrangement, Paleodictyon isp. A compares reasonably closely with both $P$. (Glenodictyum) imperfectum Seilacher and $P$. giganteum Peruzzi, both of which are 

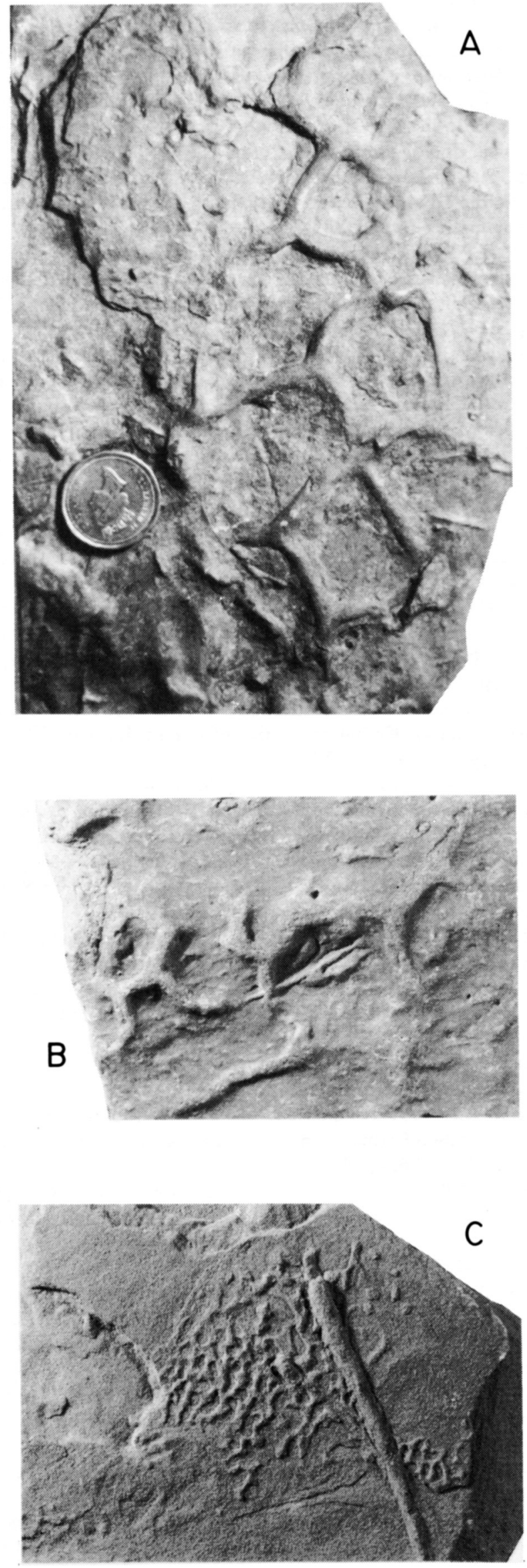

exceptionally large forms. ?Paleodictyon isp. B is only tentatively identified as such because we cannot confidently ascertain well-developed polygons characteristic of the ichnotaxon. Additionally, superficially similar examples have been described by authors such as Osgood (1970) and Benton and Gray (1981) as being inorganic in origin.

\section{Discussion}

The ichnotaxon Paleodictyon has previously been recorded in eastern Canada from the Cambrian of Newfoundland (Crimes and Anderson, 1985) and Nova Scotia (Pickerill and Keppie, 1981; Waldron, 1988), and the Carboniferous of New Brunswick (Pickerill, 1990). To our knowledge, this is its first recording from Ontario and, indeed, its first documented occurrence in Canada in rocks of Ordovician age. As briefly reviewed by Pickerill (1990) and Crimes and Crossley (1991), the origin and function of Paleodictyon have been actively debated since its initial description by Meneghini (in Murchison, 1850). Although most researchers now accept a biogenic origin, several enigmas still remain to be resolved (see also Miller, 1991). Unfortunately, the small amount of material from the Georgian Bay Formation and its generally poor and incomplete preservation precludes consideration of these enigmas. Nevertheless, its occurrence there in an Ordovician shelf setting, as interpreted for the formation, is worthy of additional commentary.

As noted previously, several authors (e.g., Crimes and Crossley, 1991; Crimes et al., 1992) have suggested that Paleodictyon initially 'evolved' in Early Cambrian shallow water niches and then 'retreated' to deeper-water habitats. Bottjer and Jablonski (1988) and Crimes and Droser (1992) suggested that the process of environmental 'retreat' was biologically-driven and that possible mechanisms included competitive exclusion by superior innovations that originated onshore and, or, passive replacement, because speciation in more stable offshore environments may have been more predictable than in less stable onshore equivalents. Whatever the cause, with respect to Paleodictyon the environmental 'retreat' intimated by Crimes and Crossley (1991) and Crimes et al. (1992) is obviously not so straightforward as suggested. Initially, it must be recalled that Archer and Maples (1984) and Pickerill (1990) recorded Paleodictyon in non-marine strata of Carboniferous age. This suggests that the 'retreat' process also involved non-marine as well as offshore or deep-sea habitats. Retreat into non-marine habitats is not included within the definitions of 'retreat' and 'expansion' by Bottjer et al. (1988). Instead, the descriptor 'amphidromy' has been utilized by Maples and Archer (1989) to reflect the migration of marine ichnotaxa into a non-

Fig. 2. (A) Paleodictyon isp. A from the Humber River Valley (Baby Point), Toronto (ROM 49424), x 0.8; (B) Paleodictyon isp. A from Workman's Creek (ROM 49624), x 0.6; (C) ?Paleodictyon isp. B from Highway 401 at Highway 403 overpass, Mississauga (ROM 49625), x 0.8. All specimens preserved in positive hyporelief. 
marine environment (or vice versa). Implicit in the concept of amphidromy is that it may or may not involve retreat or expansion, though predictably expansion would be the norm. Providing a non-marine ichnotaxon does not simply reflect behavioural convergence, that is difficult if not impossible to demonstrate, then it is logical to assume that any amphidromic process is initiated from shallow-water marine environments. Indeed, amphidromy is prevalent today among organisms in nearshore environments and undoubtedly was well-established in the Palaeozoic (Maples and Archer, 1989). This leads us to believe, therefore, that previous suggestions of the post-Early Cambrian retreat of Paleodictyon into deeper water habitats requires some modification.

The occurrence of Paleodictyon in the Georgian Bay Formation demonstrates that at least to the Late Ordovician the operative migratory process was one of expansion rather than retreat. Interestingly, in this context it is notable that Häntzschel (1964) recorded Paleodictyon from Cretaceous epicontinental deposits of Westphalia and more recently Hantzpergue and Branger (1991) documented neritic examples from the Jurassic of Aquitaine. Perhaps, therefore, the expansion process continued well into the Mesozoic and additional shallow-water marine examples of Paleodictyon await documentation. An alternative scenario is that Paleodictyon became re-established in shallow water Mesozoic seas following post-Ordovician retreat into deeper water. However, if in fact the non-marine occurrences reflect amphidromy rather than convergent evolution, this would suggest persistence of shallow-water marine Paleodictyon to, at least, the Carboniferous.

\section{Acknowledgements}

We thank A. Gómez, R. McCulloch and D. Tabor for technical assistance and D. Keighley for reading an initial version of the manuscript. J. Riva and $\mathrm{H}$. Williams provided constructive reviews and J. Waddington of the Royal Ontario Museum provided repository numbers for specimens described herein. Financial support was provided by a Natural Sciences and Engineering Council of Canada operating grant to R.K.P. which is gratefully acknowledged.

Archer, A.W. and Maples, C.G. 1984. Trace-fossil distribution across a marine-to-nonmarine gradient in the Pennsylvanian of southwestern Indiana. Journal of Paleontology, 58, pp. 448-466.

Benton, M.J. and Gray, D.I. 1981. Lower Silurian distal shelf storm-induced turbidites in the Welsh Borders: sediments, tool marks and trace fossils. Journal of the Geological Society of London, 138, pp. 675-694.

BotTJER, D.J. and JABLONSKI, D. 1988. Paleoenvironmental patterns in the evolution of post-Paleozoic benthic marine invertebrates. Palaios, 3, pp. 540-560.

Bottjer, D.J., Droser, M.L., and Jablonski, D. 1988. Paleoenvironmental trends in the history of trace fossils. Nature, 333, pp. 252-255.
Crimes, T.P. and Anderson, M.M. 1985. Trace fossils from Late Precambrian-Early Cambrian of southeastern Newfoundland (Canada): temporal and environmental implications. Journal of Paleontology, 59, pp. 310-343.

Crimes, T.P. and Crossley, J.D. 1991. A diverse ichnofauna from Silurian flysch of the Aberystwyth Grits Formation, Wales. Geological Journal, 26, pp. 27-64.

Crimes, T.P. and Droser, M.L. 1992. Trace fossils and bioturbation: the other fossil record. Annual Review of Ecology and Systematics, 23, pp. 339-360.

Crimes, T.P., Garcia Hidalgo, J.F., and Poire, D.G. 1992. Trace fossils from Arenig flysch sediments of Eire and their bearing on the early colonisation of the deep seas. Ichnos, 2 . pp. 61-77.

Hants peroue, P. and Branoer, P. 1991. L'ichnogente Paleodictyon dans les dépôts néritiques de l'Oxfordien Supérieur Nord-Aquitain (France). Geobois, 25, pp. 195-205.

Häntzschel, W. 1964. Spurenfossilien und Problematica im Campan von Beckum (Westf.). Fortschrifte in der Geologie von Rheinland und Westfalenen, 7, pp. 295-308.

KerR, M. and Eyles, N. 1991. Storm-deposited sandstones (tempestites) and related ichnofossils of the Late Ordovician Georgian Bay Formation, southern Ontario, Canada. Canadian Journal of Earth Sciences, 28, pp. 266-282.

Maples, C.G. and ArCher, A.W. 1989. The potential of Paleozoic nonmarine trace fossils for paleoecological interpretations. Palaeogeography, Palaeoclimatology, Palaeoecology, 73, pp. 185-195.

MCCANN, T. and Pickerill, R.K. 1988. Flysch trace fossils from the Cretaceous Kodiak Formation of Alaska. Journal of Paleontology, 62, pp. 330-348.

Middleton, G.V. 1987. Geological setting of the northem Appalachian Basin during the Silurian. In Sedimentology, stratigraphy and ichnology of the Lower Silurian Medina Formation in New York and Ontario. Edited by W. Duke. Society of Economic Paleontologists and Mineralogists, Eastern Section, Annual Field Trip Guidebook, pp. 1-15.

MILLER, W., III. 1991. Paleoecology of graphoglyptids. Ichnos, 1, pp. 305-312.

Murchison, R.I. 1850. Memoria sulla struttura geologica delle Alpi, delle Apennini e dei Carpazi. Stamperia granucale, Firenze, 528 p.

Oscood, R.G., JR. 1970. Trace fossils of the Cincinnati area. Paleontographica Americana, 6, pp. 277-444.

Pickerill, R.K. 1990. Nonmarine Paleodictyon from the Carboniferous Albert Formation of southern New Brunswick. Atlantic Geology, 26, pp. 157-163.

Pickerill, R.K. and KepPIE, J.D. 1981. Observations on the ichnology of the Meguma Group (?Cambro-Ordovician) of Nova Scotia. Maritime Sediments and Atlantic Geology, 17. pp. 130-138.

Russell, D.J. and Telford, P.G. 1983. Revisions to the stratigraphy of the Upper Ordovician Colling wood beds of Ontario a potential oil shale. Canadian Journal of Earth Sciences, 20, pp. 1780-1790.

Seilacher, A. 1964. Biogenic sedimentary structures. In Approaches to Paleoecology. Edited by J. Imbrie and N.D. Newell. Wiley, New York, pp. 296-316.

1967. Bathymetry of trace fossils. Marine Geology, 5, pp. 189-200.

Stanley, D.C.A. and Pickerill, R.K. (In press). Fustiglyphus annulatus from the Ordovician of Ontario, Canada, with a 
systematic review of the ichnogenera Fustiglyphus Vyalov 1971 and Rhabdoglyphus Vassoievich 1951. Ichnos.

WALDRON, J.W.F. 1988. Determination of finite strain in bedding surfaces using sedimentary structures and trace fossils: a comparison of techniques. Joumal of Structural Geology, 10 , pp. 273-281. 